\title{
Biogas Production by Pilot-Scale Anaerobic Co-Digestion and Life Cycle Assessment Using a Real Scale Scenario: Independent Parameters and Co-Substrates Influence
}

\author{
Jhessica Mosquera ${ }^{1}$, Carol Rangel ${ }^{2}$, Jogy Thomas ${ }^{3}$, Angelica Santis ${ }^{4}$, Paola Acevedo ${ }^{4}$ and Ivan Cabeza ${ }^{5, *}$ \\ 1 Department of Environmental Engineering, Universidad Santo Tomás, Bogotá 110231, Colombia; \\ jhessica.mosquera@usantotomas.edu.co \\ 2 Department of Process Engineering, Universidad EAN, Bogotá 110221, Colombia; \\ crangel46372@universidadean.edu.co \\ 3 Department of Electrical and Electronics Engineering, Karunya Institute of Technology and Science, \\ Coimbatore 641114, India; Jogythomas1987@gmail.com \\ 4 Department of Industrial Engineering, Universidad Cooperativa de Colombia, Bogotá 111311, Colombia; \\ angelica.santisn@campusucc.edu.co (A.S.); paola.acevedop@ucc.edu.co (P.A.) \\ 5 Department of Engineering Design and Innovation, Politécnico Grancolombiano, Bogotá 111711, Colombia \\ * Correspondence: icabeza@poligran.edu.co
}

\section{check for} updates

Citation: Mosquera, J.; Rangel, C.; Thomas, J.; Santis, A.; Acevedo, P.; Cabeza, I. Biogas Production by Pilot-Scale Anaerobic Co-Digestion and Life Cycle Assessment Using a Real Scale Scenario: Independent Parameters and Co-Substrates Influence. Processes 2021, 9, 1875. https://doi.org/10.3390/pr9111875

Academic Editors: Anna Trubetskaya, Lara Carvalho and Jhuma Sadhukhan

Received: 3 August 2021

Accepted: 30 September 2021

Published: 21 October 2021

Publisher's Note: MDPI stays neutral with regard to jurisdictional claims in published maps and institutional affiliations.

Copyright: (c) 2021 by the authors. Licensee MDPI, Basel, Switzerland. This article is an open access article distributed under the terms and conditions of the Creative Commons Attribution (CC BY) license (https:// creativecommons.org/licenses/by/ $4.0 /)$.

\begin{abstract}
This study evaluates the performance of different agricultural by-products to identify the potential effect of independent variables, using as the dependent variable the biogas production. A Box-Behnken experimental design was carried out in a pilot-scale plant of four stirred stainless-steel digesters under mesophilic semi-continuous digestion. The results obtained support the creation of a technical framework to scale up the process and further evaluation of the potential environmental impacts through life cycle assessment (LCA) methodology. A stable behaviour was achieved in 12 of the 13 experiments proposed. The highest value of daily biogas production was $2200.15 \mathrm{~mL} \mathrm{day}^{-1}$ with a stabilization time of 14 days, an organic loading rate of $4 \mathrm{~g}$ VS feed daily, low $\mathrm{C} / \mathrm{N}$ ratio and a 1:1 relation of nitrogen providers. The concentrations of $\mathrm{CH}_{4}$ remained stable after the production stabilization and an average biogas composition of $60.6 \% \mathrm{CH}_{4}, 40.1 \% \mathrm{CO}_{2}$ and $0.3 \% \mathrm{O}_{2}$ was obtained for the conditions mentioned above. Therefore, the real scale plant was estimated to manage 2.67 tonnes of residual biomass per day, generating $369.69 \mathrm{kWh} \mathrm{day}^{-1}$ of electricity. The LCA analysis confirms that the co-digestion process evaluated is a feasible and environmentally sustainable option for the diversification of the Colombian energy matrix and the development of the agro-industrial sector.
\end{abstract}

Keywords: residual biomass; Box-Behnken design; biogas production potential; anaerobic codigestion; life cycle assessment

\section{Introduction}

Energy consumption is strongly related to economic growth, and this relationship has given electricity markets an essential place in the economy of developing countries [1] In Colombia, the national energy demand has sustained an increase in the last decades; equally, it was estimated that between 2016 and 2030 the electric energy demand will rise by over 52\% [2]. Moreover, the participation of renewable energy sources in its energetic matrix is represented by hydropower, which generates $67.1 \%$ of the total electric energy generation [3]. Consequently, previous researchers have pointed to the potential of biomass to supply heat, combined heat and energy, as well as bio-based products such as biofuels and building block chemicals [4,5]. Therefore, one of the main priorities for the diversification of the Colombian energy matrix is the inclusion of renewable energy alternatives, such as the transformation of biomass for energy production. 
Biomass for energy production involves different technologies for the valorisation of organic waste through biochemical conversions, and within these alternatives is anaerobic digestion (AD) for biogas production [6]. AD is a waste valorisation technology that has been studied and used worldwide due to its advantages over other organic waste treatments and bioenergy processes. Likewise, the anaerobic co-digestion (AcoD) allows the inclusion of different organic residues in order to avoid inhibitions and boost the production; it is clear that a mixture of substrates in the organic load optimizes the carbon/nitrogen $(\mathrm{C} / \mathrm{N})$ ratio by the dilution of nitrogen, improves the biodegradation and dilutes the potential inhibitory or toxic compounds, among others benefits [7]. The studies over the optimization of the AcoD conditions and the evaluation of the process efficiency through operational conditions analysis and reactor design will determine the potential of AcoD technology to large-scale implementation [8].

In the AcoD process, the characterization of the physicochemical properties of substrates is necessary for the process definition and for the prediction of biogas production; the correct mixture of carbon- and nitrogen-rich by-products improves the process stability of the nutrient contents required for the microorganisms [9]. In semi-continuous processes, the main operational variable is the organic loading rate (OLR), which is linked to an increase in methane production; this variable allows for the control of total solids (TS) converted to biogas, however, overloading by carbon-rich co-substrates could inhibit the process, causing the acidification of the system [8]. Lab-scale and pilot-scale experiments are useful as inputs for the simulation of AD under different conditions and for the correct transfer to the technology that represents real benefits to the different sectors [10].

In this framework, the implementation of agricultural by-products in AcoD processes for energy production is a potential that grows vigorously and rapidly [11], increases employment, supports ecosystems and biodiversity and reduces waste and pollution [12]. In addition, it brings many environmental benefits: the reduction of $\mathrm{CH}_{4}$ emissions from organic matter degradation and avoids the concentration of atmospheric $\mathrm{CO}_{2}$ from fossil fuel consumption by diversifying the energy supply. Furthermore, related to substrate management, the hermetic storage of manure prevents the emission of $\mathrm{N}_{2} \mathrm{O}$, enhances the soil nitrogen absorption using the digestate as fertilizer and reduces ammonia emissions.

The evaluation of the potential environmental impacts from new renewable technologies to generate a holistic view of the technology into consideration [13] is key for decision makers. The Life Cycle Assessment (LCA) methodology is an essential method for environmental management and decision making, allowing researchers to evaluate, compare and improve the production pathway of a good or service. Several studies have used LCA methodology to assess the environmental and potential improvements on the inclusion of biogas systems in agriculture, which guarantee the understanding and knowledge of environmental cost and benefits related to the specific scope and boundaries defined $[14,15]$.

LCA, along with a detailed technical and economic evaluation, will support the implementation of new technologies with lower environmental impacts, higher energy balance and value-added product generation [16]. Certainly, few researchers have conducted studies to evaluate the performance of the ACoD for biogas production and other value-added products, estimating the influence of different independent parameters and specific cosubstrates (highly available residual biomass) and combined with an LCA to quantify the potential impacts of the implementation of the technology in a real scenario in countries such as Colombia [17,18]. Although Mendieta et al., 2021 [19] assessed the implementation of low-cost digesters as an alternative for the mitigation of the impacts associated with noncentrifugal cane sugar sector in Colombia, there is no study assessing the environmental benefits over the implementation of centralized biogas production systems.

There is a high availability of crop and livestock residues in Colombia as agribusiness GDP participation expands; a 4\% growth is expected for the 2021 balance. It is recorded that one of the largest bottled fruit drink industries uses more than 28.900 tonnes of fruits annually for its processes. The fruits are: blackberry, mango, lulo and guayaba; $25-40 \%$ 
of these fruits are turned into residue [20]. Likewise, the cocoa industry produced more than 59.711 tonnes of cocoa in 2019, from which $70 \%$ is turned into residue after the transformation process [21]. On the other hand, the livestock sector registered a swine population of more than 5.9 million, located in 6 of the wealthier regions of the country; lifting pigs produce around $2.35 \mathrm{~kg}$ of manure per day [22]. In turn, wastewater treatment systems produce great amounts of sewage sludge from purification processes [23].

For this purpose, the aim of this paper is the evaluation of the anaerobic co-digestion of four agro-industrial by-products, pig manure (PM), sewage sludge (SS), residues from the bottled fruit drinks industry (RBFDI) and cocoa industry residue (CIR), to identify the potential effect of different control variables for the maximization of the biogas production in pilot-scale reactors operated in a semi-continuous regime. Therefore, the starting point was the definition of the constant operational conditions ( $\mathrm{pH}$, temperature and agitation), and the generation of a Box-Behnken design for the evaluation of the organic loading rate $\left(\right.$ OLR fed day $\left.^{-1}\right), \mathrm{C} / \mathrm{N}$ ratio adjustment and the nitrogen provider substrate as independent variables. In addition, the results presented in this study are useful for the development of Colombian agro-industries and the diversification of the energy matrix when evaluated with an LCA methodology. Specifically, these results enable the scaling-up of this kind of process and the implementation of distributed generation facilities.

\section{Materials and Methods}

\subsection{Substrates Characteristics}

The raw materials evaluated in this work are pig manure (PM), residues from the bottled fruit drinks industry (RBFDI), sewage sludge (SS) and cocoa industry residue (CIR); those residues correspond to rural/agricultural processes previously studied by Mosquera et al., 2020 [24]. Pig manure was obtained from the Agricultural Research Centre Marengo (C.A.M) of the Universidad Nacional de Colombia located in Mosquera-Cundinamarca. The animals are fed with commercial feeding formulas. RBFDI were simulated based on the references related to the residual streams of this sector: mango, banana, blackberry, lulo and passion fruit. Sewage sludge (SS) was obtained from a water treatment plant in Madrid-Cundinamarca (Colombia). Cocoa industry residue (CIR) was simulated from references of this industry; there were used the cocoa husks and pods obtained from a private farm in Santander, Colombia [25]. A mechanical pre-treatment was applied to RBFDI and CIR, which were reduced to a particle size of approximately $0.5 \mathrm{~mm}$. The residues were preserved in a freezer at $-4{ }^{\circ} \mathrm{C}$ to avoid microbiological degradation before the assay.

Mesophilic inoculum $\left(35 \pm 1^{\circ} \mathrm{C}\right)$ was used in all the experiments to guarantee proper start-up conditions in each reactor. The inoculum was obtained from an anaerobic digester (dairy industry water treatment plant) from Alpina Company in Sopó-Cundinamarca. This inoculum is considered to have the adapted bacteria for the operating conditions arranged for the experiments. Table 1 presents the physicochemical characteristics of the inoculum and each substrate, including moisture content, Kjeldahl total nitrogen (KTN), total solids (TS), volatile solids (VS), C/N and chemical oxygen demand (COD).

Table 1. Physicochemical characteristics of the inoculum and substrates ${ }^{a}$.

\begin{tabular}{|c|c|c|c|c|c|c|}
\hline & & CIR & SS & PM & RBFDI & Inoculum \\
\hline pH (1:5 Extract) & & $5.42 \pm 0.13$ & $7.55 \pm 0.15$ & $7.16 \pm 0.22$ & $4.2 \pm 0.20$ & \\
\hline Moisture ${ }^{\mathrm{b}}$ & $\%$ & $89.62 \pm 0.07$ & $39.56 \pm 0.03$ & $74.65 \pm 0.02$ & $70.67 \pm 0.03$ & $91.45 \pm 0.02$ \\
\hline $\mathrm{KTN}^{\mathrm{c}}$ & $\%$ & $0.70 \pm 0.02$ & $0.91 \pm 0.07$ & $1.38 \pm 0.08$ & $1.16 \pm 0.01$ & \\
\hline TS & $\%$ & $10.37 \pm 0.02$ & $60.43 \pm 0.18$ & $29.32 \pm 0.04$ & $26.12 \pm 0.01$ & $20.50 \pm 0.01$ \\
\hline VS & $\%$ & $7.94 \pm 0.01$ & $8.49 \pm 0.04$ & $22.92 \pm 0.07$ & $22.73 \pm 0.07$ & $16.72 \pm 0.08$ \\
\hline $\mathrm{C} / \mathrm{N}$ & & 59.57 & 14.88 & 33.18 & 48.01 & \\
\hline $\mathrm{COD}^{\mathrm{b}}$ & $\mathrm{g} \mathrm{L}^{-1}$ & 8.17 & 109.5 & 24.6 & 8.62 & \\
\hline
\end{tabular}

${ }^{a}$ Average \pm standard deviation, over three samples. ${ }^{b}$ Sample on wet basis. ${ }^{c}$ Sample on dry basis. 


\subsection{Experimental Design}

A Box-Behnken design was built based on the individual physicochemical characterization of the residues. The independent variables evaluated were the $\mathrm{C} / \mathrm{N}$ ratio, organic loading rate fed daily (OLR g VS fed day ${ }^{-1}$ ) and the percentage of the source of nitrogen. Each variable had three different levels: $\mathrm{C} / \mathrm{N}$ ratio $(25,35$ and 45$), \mathrm{OLR} g$ VS fed day ${ }^{-1}$ $(2.5,3.25$ and 4$)$. For the percentage of the source of nitrogen, the three levels were defined as follows: samples containing only pig manure as a nitrogen source $(100 \%)$, samples containing only sewage sludge as a nitrogen source $(0 \%)$ and those containing both substrates $(1: 1$ or $50 \%)$. The experimental design contained a total of 13 combinations (Table 2). In this case, the $\mathrm{C} / \mathrm{N}$ ratio is adjusted according to the characteristics of each waste [26], and the $\mathrm{g}$ VS of the substrates and inoculum $(\mathrm{S} / \mathrm{X})$ ratio was determined as three (3) based on previous research works $[24,27,28]$. In all cases, the experimental design attends for the proper quantification of the independent variable (biogas production).

Table 2. Experimental design description and composition.

\begin{tabular}{cccc}
\hline Combination & $\mathbf{C} / \mathbf{N}$ & $\mathbf{\%}^{\mathbf{a}}$ & OLR (g VS Fed Day $\left.^{-\mathbf{1}}\right)$ \\
\hline C-1 & 25 & 0 & 3.25 \\
C-2 & 45 & 0 & 3.25 \\
C-3 & 25 & 100 & 3.25 \\
C-4 & 45 & 100 & 3.25 \\
C-5 & 25 & 50 & 2.5 \\
C-6 & 45 & 50 & 2.5 \\
C-7 & 25 & 50 & 4 \\
C-8 & 45 & 50 & 4 \\
C-9 & 35 & 0 & 2.5 \\
C-10 & 35 & 100 & 2.5 \\
C-11 & 35 & 0 & 4 \\
C-12 & 35 & 100 & 4 \\
C-13 & 35 & 50 & 3.25 \\
\hline
\end{tabular}

A Box-Behnken experimental design is presented, where the independent variables evaluated were the $\mathrm{C} / \mathrm{N}$ ratio, organic loading rate fed daily (OLR g VS fed day ${ }^{-1}$ ), and the percentage of the source of nitrogen, ${ }^{\mathrm{a}}$ where $0 \%$ responds to the addition of only sewage sludge as a nitrogen source, $100 \%$ only pig manure and $50 \%$ both substrates in equal quantities.

\subsection{Experimental Setup}

The AcoD processes were carried out in a pilot-scale plant of four identical semicontinuously stirred stainless-steel digesters that handle a workload of $4 \mathrm{~L}$ (total volume 5 L) (see Figure 1). Reactors are provided with three automatized systems to monitor each process: temperature system, agitation system and $\mathrm{pH}$ measurement system. For the temperature system, reactors are provided with a jacket where a heating fluid (thermal oil) is contained and a PT-100, which is used to record the internal temperature; the recorded temperature is sent to an embedded Arduino system that allows the control of temperature set point. The agitation system is constituted by a servomotor, palettes with four blades each and a driver for the control of the agitation speed. The $\mathrm{pH}$ measurement system gives $\mathrm{pH}$ values in real-time by HI $6100405 \mathrm{pH}$ meters and lecture panel. Moreover, the reactors have a side orifice for the outlet of the digested effluent and, at the top, a biogas output tubing that conduces to the RITTER flowmeter for each of the reactors [29].

Regarding the experimental design, to guarantee the stability of the process, the following operative conditions were established: mesophilic temperature $\left(35 \pm 1{ }^{\circ} \mathrm{C}\right)$, agitation speed of 30 RPM, a pH between 6.5 and 7.5 and a hydraulic retention time (HRT) between 17 and 21 days; these values are supported in previous research [30]. During the process, samples were taken to monitor physicochemical parameters every 5 days (COD, tVFA, Alkalinity, g VS). At the same time, within the monitoring, gas sampling was carried out to evaluate the composition of the biogas and record the flow of production of the biogas generated. 


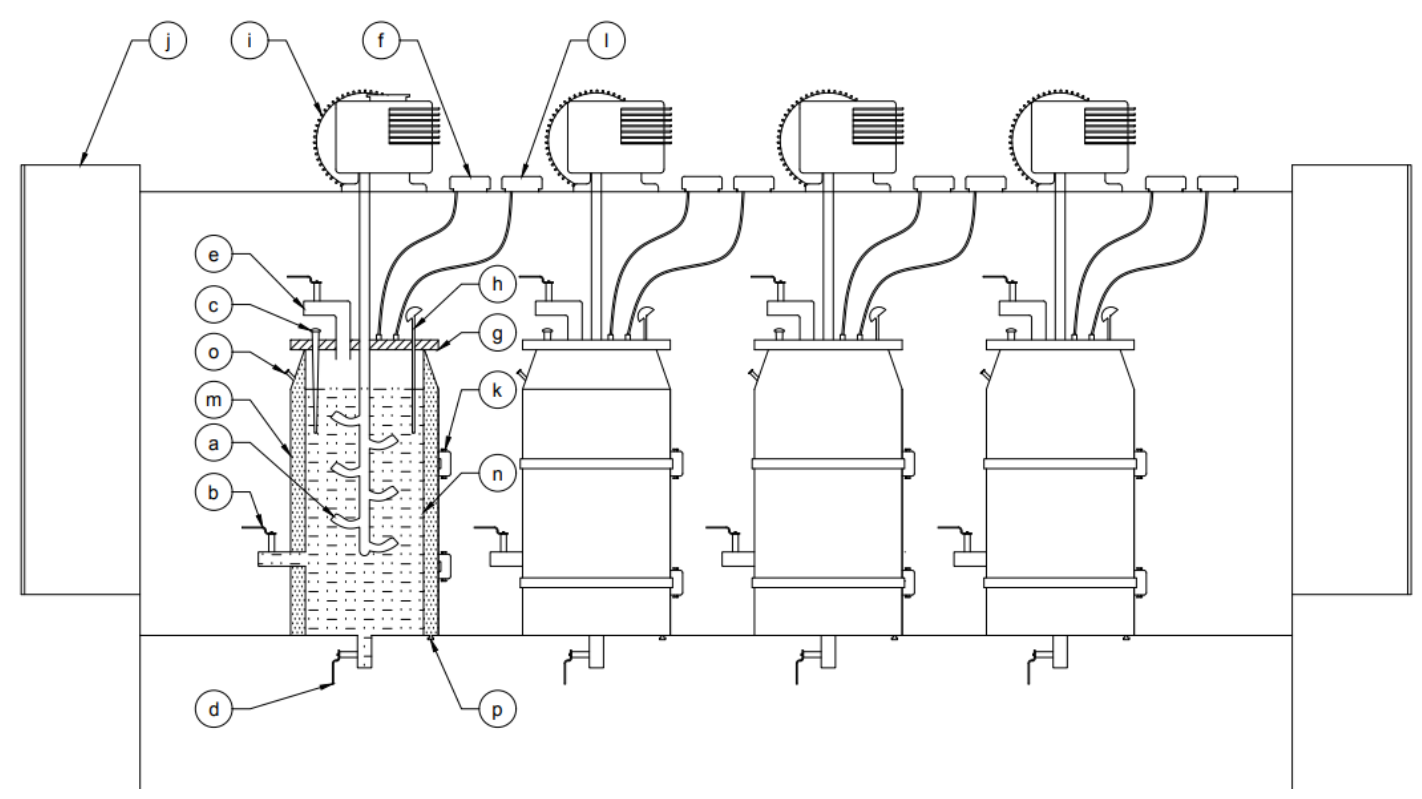

Figure 1. Semi-continuous anaerobic co-digestion pilot-scale plant. (a) Stirrer, (b) collection valve, (c) pH meter, (d) drainage valve, (e) milligas-counter, (f) acid supply pump, (g) closing lid, (h) temperature sensor, (i) servomotor, (j) control panel, (k) heating system, (1) base supply pump, $(\mathbf{m})$ reactor, $(\mathbf{n})$ separation chamber, $(\mathbf{o})$ heating fluid inlet, (p) heating fluid outlet.

\subsection{Analytical Methods}

Total Solids and Volatile Solids of the initial substrates and the digestate were determined by drying the samples at $105 \pm 5^{\circ} \mathrm{C}$ in a drying oven and ignition at $550 \pm 10{ }^{\circ} \mathrm{C}$ in a muffle furnace, this according to 2540B APHASM and D3174 of the American Society for Testing and Materials (ASTM) respectively. Measurements of $\mathrm{pH}$ were determined using a pH meter Edge model HI2002, following the standard test method D 4972-01 of the ASTM. Total volatile fatty acids (tVFA) and Alkalinity were measured by back-titration according to [31]. The Chemical Oxygen Demand (COD) was measured using commercial vials with a range of 0 to $150 \mathrm{mg} \mathrm{L}^{-1}$ (HI 93752). Kjeldahl total nitrogen (KTN) was determined according to the D1426 of the ASTM. The quantification of the volume of biogas produced was performed by RITTER flowmeters (MilligasCounter-RIGAMO software), which allows the total gas measurement in real time. In addition, the gas composition measurements $\left(\mathrm{CO}_{2}, \mathrm{CH}_{4}\right.$ and $\left.\mathrm{O}_{2} \%\right)$ were determined by the gas analyzer Biogas 5000 (Geotech-Landtec).

\subsection{Statistical Analysis}

\section{Second-Order Polynomial Regression}

The experimental Box-Behnken design enabled the construction of second-order polynomials associating the independent variables and its interactions with the response variable (dependent variable) [32]. The polynomial model used was of the following type (Equation (1)):

$$
Z=a_{0}+\sum_{i=1}^{n} b_{i} x_{n i}+\sum_{i=1: j=1}^{n} d_{i j} X_{n i} X_{n j} \quad(i<j)
$$

where $Z$ and $X_{n i}$ denote dependent and normalized independent variables, respectively, $a_{0}$ is a constant and $b_{i}, c_{i}, d_{i j}$ are the regression coefficients obtained from experimental data.

Following this, the model diagnostic was carried out comparing the variation explained by the model and the variation of model residuals through the analysis of variance (ANOVA). A good overview of polynomial regression and model diagnostic is described by Mäkelä et al., 2017 [33], who presented a tutorial review over experimental design and response surface methodology.

The standardized effects of the independent variables and their interactions were represented through a Pareto chart, which is calculated by the ratio between the effect value and the standard deviation obtained during the optimization [34]. The simulation was 
performed in the Statgraphics software, version Centurion 19, Statgraphics Technologies, Inc., The Plains, VA, USA.

\subsection{Life Cycle Assessment}

The potential environmental impacts of the best treatment combination were estimated applying the LCA methodology established by the International Organization for Standardization ISO 14040 [35]:

1. Goal and scope definition;

2. Process design and construction of mass and energy balances for the inventory analysis;

3. Impact assessment using SimaPro software;

4. Interpretation of the assessment and improvements suggestions.

The current work aims to evaluate an alternative for the reduction of the environmental impacts associated with the actual management of the residual biomass from agribusiness activities that take place in Cundinamarca, Colombia. Therefore, the LCA takes into consideration the best operative conditions determined for the implementation of a valorisation pathway, which includes the energy from biogas production and treated digestate as products. The functional unit (FU) of this study was established as the management of the tonnes of residual biomass fed per day to produce $1 \mathrm{kWh}$ of energy. Thus, the process design will be based on this FU. Furthermore, the inventory data was taken from the mass and energy balances proposed by the pilot-scale experiments, while the information of substrates availability, chemicals, and energy carries associated with the process is taken from literature and databases.

Furthermore, it was assumed that the plant would have an average operation capability of $80 \%$, considering a continuous process with a hydraulic retention time of 17 days. The process boundary encompasses the delivery of the substrates, mechanical pre-treatment, AcoD process, biogas purification, biogas combustion in a power generation engine and digestate production. The energy demand of the real-scale plant was supplied from the Colombian electricity market and $35 \%$ of the biogas produced to heat the reactor. For the present study, the electrical efficiency of the considered power engine was assumed to be $0.35[36]$.

\section{Results and Discussion}

\subsection{Box-Behnken Analysis}

\subsubsection{Biogas Yields}

The results of the biogas production obtained for the AcoD tests in a semi-continuous regime are presented in Figure 2. It is appreciable that the combination that achieved the highest cumulative biogas production is combination 2, which contains sewage sludge as the primary source of nitrogen, has a C/N ratio of 45 and an OLR of $3.25 \mathrm{~g}$ VS fed day ${ }^{-1}$. The reactor was fed for 21 days. During this time, the $\mathrm{pH}$ remained between 6.6 and 6.85 with a tVFA/Alkalinity ratio of 0.37 , which responds to a low accumulation of VFAs (an average value of $244 \mathrm{mg} \mathrm{L}^{-1}$ ) at the end of the co-digestion process. Under these conditions, the reactor was able to stabilize its production between days 15 and 16, with a total biogas production of $744.31 \mathrm{~mL} \mathrm{~g} \mathrm{VS}^{-1}$ and a biogas composition of $51.3 \pm 0.31 \% \mathrm{CH}_{4}$, $44.8 \pm 0.27 \% \mathrm{CO}_{2}$ and $0.2 \pm 0.06 \% \mathrm{O}_{2}$.

In comparison, combination 1 performed one of the lowest biogas productions, $138.33 \mathrm{~mL} \mathrm{~g}^{-1}$ VS during 17 days of stabilization, where the values for the OLR and the nitrogen provider were the same as combination 2 and the $C / N$ value was 25 . For all the combinations evaluated in the experimental design, there was a stable performance of the AcoD in terms of its biogas production. 


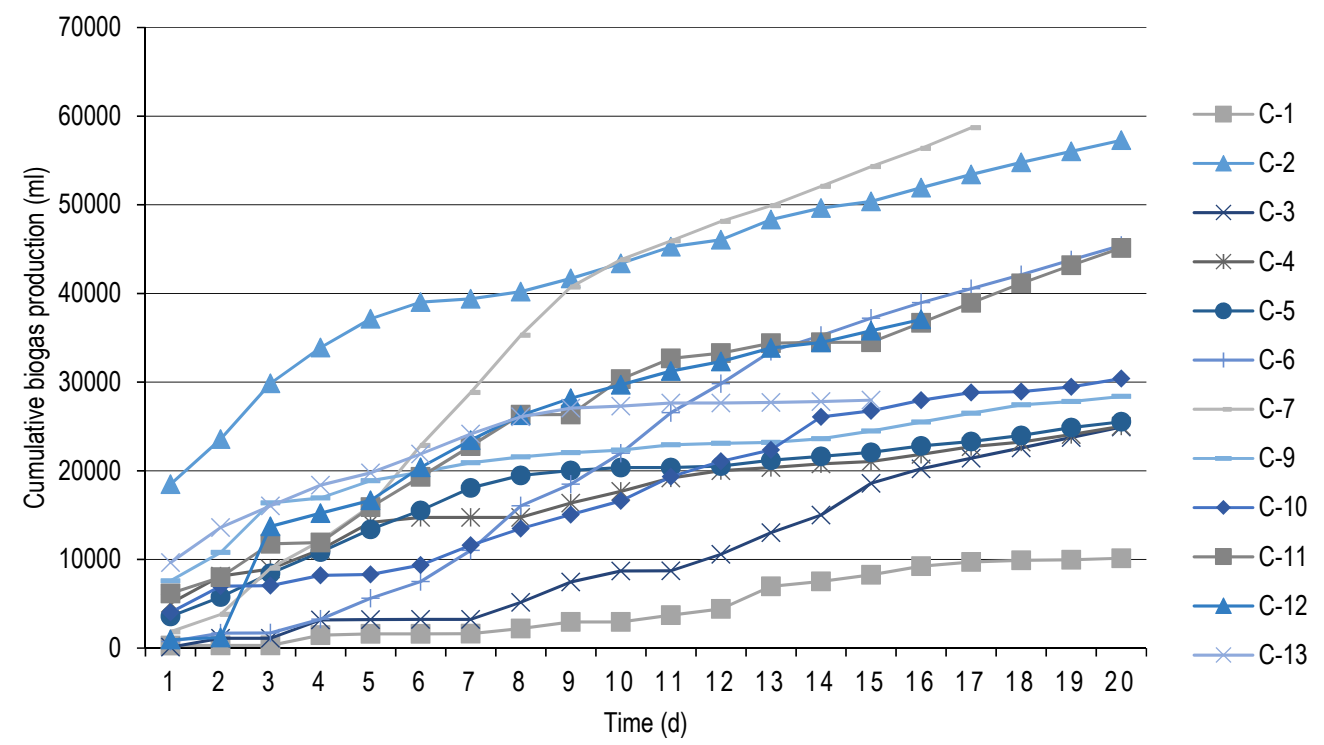

Figure 2. Cumulative biogas production of each combination evaluated.

\subsubsection{Monitoring Results}

The results associated with the monitoring of the anaerobic co-digestion process of each combination are presented in Table 3. A stable behaviour was achieved in 10 of the 13 experiments proposed, with a tVFA/Alkalinity ratio of 0.22 to 0.57 [37]. The highest value of daily biogas production was $2200.15 \mathrm{~mL}_{\text {day }}{ }^{-1}$ obtained in combination 7 , with a stabilization time of 14 days. Moreover, it had the highest daily productions with one of the shortest stabilization times, followed by combinations $11\left(2110.35 \mathrm{~mL} \mathrm{day}^{-1}\right)$ and $6\left(17,007.29 \mathrm{~mL} \mathrm{day}^{-1}\right)$. Combination 11 presented one of the highest daily productions by day 17 under similar operative conditions to combination 7 , a high OLR fed daily, low $\mathrm{C} / \mathrm{N}$ ratios (25 and 35, respectively) but different percentages for the nitrogen providers. In addition, combination 6 has contrary conditions, low OLR feeds daily, high $\mathrm{C} / \mathrm{N}$ values and a 1:1 relation between nitrogen providers, which might be associated to an equilibrium produced by the high $\mathrm{C} / \mathrm{N}$ and the low OLR values. In accordance with this, Shahbaz et al., 2020 [38] pointed that at low OLR (near $2 \mathrm{~g} \mathrm{VS}$ fed $\mathrm{L}^{-1}$ day $^{-1}$ ), anaerobic bacteria action led the consumption of the organic contents of the substrates.

Table 3. Follow-up parameters of the co-digested assays in a semi-continuous regime.

\begin{tabular}{|c|c|c|c|c|c|c|c|c|}
\hline Combinations & Stabilization Day & $\begin{array}{l}\text { Daily Biogas } \\
\text { Production } \\
\left.\text { (mL Day }^{-1}\right)\end{array}$ & $\mathrm{CH}_{4}(\%)$ & $\begin{array}{l}\text { Biogas Yield } \\
\left(\mathrm{mL} \mathrm{g}^{-1} \text { VS) }\right.\end{array}$ & $\begin{array}{l}\text { VS of Digestate } \\
\left(\mathrm{g} \mathrm{L}^{-1}\right)\end{array}$ & $\begin{array}{c}\text { COD of } \\
\text { Digestate }\left(\mathrm{g} \mathrm{L}^{-1}\right)\end{array}$ & Average pH & $\begin{array}{c}\text { tVFA/Alkalinity } \\
\text { Ratio }\end{array}$ \\
\hline$C-1$ & 17 & 375.62 & $46.9-52.7$ & 138.33 & 32.16 & 17.5 & 6.86 & 0.57 \\
\hline$C-2$ & 16 & 1400.58 & $50.7-51.3$ & 744.31 & 22.5 & 16.15 & 6.67 & 0.37 \\
\hline$C-3$ & 17 & 1333.42 & $57.5-59.9$ & 313.73 & 55.66 & 12.49 & 7.06 & 0.41 \\
\hline C-4 & 17 & 795.71 & $52.4-54.5$ & 322.5 & 10.71 & 13.45 & 6.88 & 0.23 \\
\hline C-5 & 14 & 618.63 & $54.2-55.8$ & 411.17 & 14.43 & 13.72 & 6.76 & 0.22 \\
\hline$C-6$ & 16 & 1707.29 & $57.9-59.5$ & 736.7 & 23.63 & 11.5 & 6.27 & 0.64 \\
\hline C-7 & 14 & 2200.15 & $54.7-57.5$ & 617.98 & 17.4 & 18.87 & 7.50 & 0.21 \\
\hline C-9 & 15 & 794.21 & $58.9-59.1$ & 463.02 & 23.82 & 18 & 6.60 & 0.39 \\
\hline$C-10$ & 16 & 725.94 & $56.4-59$ & 531 & 11.64 & 16 & 6.92 & 0.18 \\
\hline C-11 & 17 & 2110.35 & $54.3-55.4$ & 446.49 & 14.92 & 10.8 & 6.33 & 0.33 \\
\hline C-12 & 11 & 1230.99 & $49.8-50.3$ & 363.52 & 14.92 & 18 & 6.85 & 0.45 \\
\hline C-13 & 9 & 884.10 & $49.8-50.1$ & 396.59 & 62.84 & 15.91 & 6.37 & 0.97 \\
\hline
\end{tabular}

On the other hand, the results of the digestate analysis showed removals of VS between 57 to $84 \%$; the removals are higher than the ones reported in the literature $[39,40]$. However, the highest removal was achieved for the combinations with low OLRs (2.5 $\mathrm{g}$ VS fed day $\left.^{-1}\right)$, with a $65.1 \%$ average, and the lowest removals were for high OLR (3.25-4 feed $g$ $\mathrm{VS}_{\text {day }}{ }^{-1}$ ), $57.3 \%$ average, as expected. Moreover, there is a relevant importance in the digestate characteristics for the further generation of chemical and value-added products that may create higher economic benefits for the implementation of this technology under 
a biorefinery scope $[13,41]$. Typical digestate components from similar process are $4.6 \mathrm{~kg}$ $\mathrm{N}, 1.8 \mathrm{~kg} \mathrm{P}_{2} \mathrm{O}_{5}$ and $3.8 \mathrm{~kg} \mathrm{~K}_{2} \mathrm{O}$ (Dry mass 5.7\%) per tonne [36]. In addition to the present study focusing on the production of biogas, there are different possible products if the process is encompassed in a biorefinery scheme.

Moreover, the results confirm that the stirring conditions have boosted the production further from optimal estimations on batch reactors with the same residual biomass, where for a combination evaluated under similar conditions ( $\mathrm{C} / \mathrm{N}$ ratio of $28-40, \mathrm{~S} / \mathrm{X}$ of 3 and sewage sludge as nitrogen provider), the biogas yield is around 320 to $380 \mathrm{~mL} \mathrm{~g}^{-1}$ VS [24]. Proper stirring conditions are proved to promote the symbiotic relation between methanogens and acetogens and also favours the distribution of the macro and micronutrients [42].

Figure 3 shows the behaviour of the process in terms of the tVFA/Alkalinity ratio, which is a critical operational parameter for the recognition of inhibition processes [43]. During the initial stages of the AD process, the VFA concentration is expected to increase, accumulating for further consumption; therefore, the acidification of the process must be reversible. If the VFA remains high and the alkalinity in the reactor is not recovered, a slow growing of methanogens is presented, limiting the direct or indirect VFA degradation. This causes an imbalance for continued VFA accumulation, which lowers the alkalinity, reducing the $\mathrm{pH}$ to $<5.5$ and restricting the AD process [44]. Indeed, combinations with high organic loads and high $\mathrm{C} / \mathrm{N}$ values presented inhibitions of the microorganism consortia during the early stages of the process because of the accumulation of tVFA.

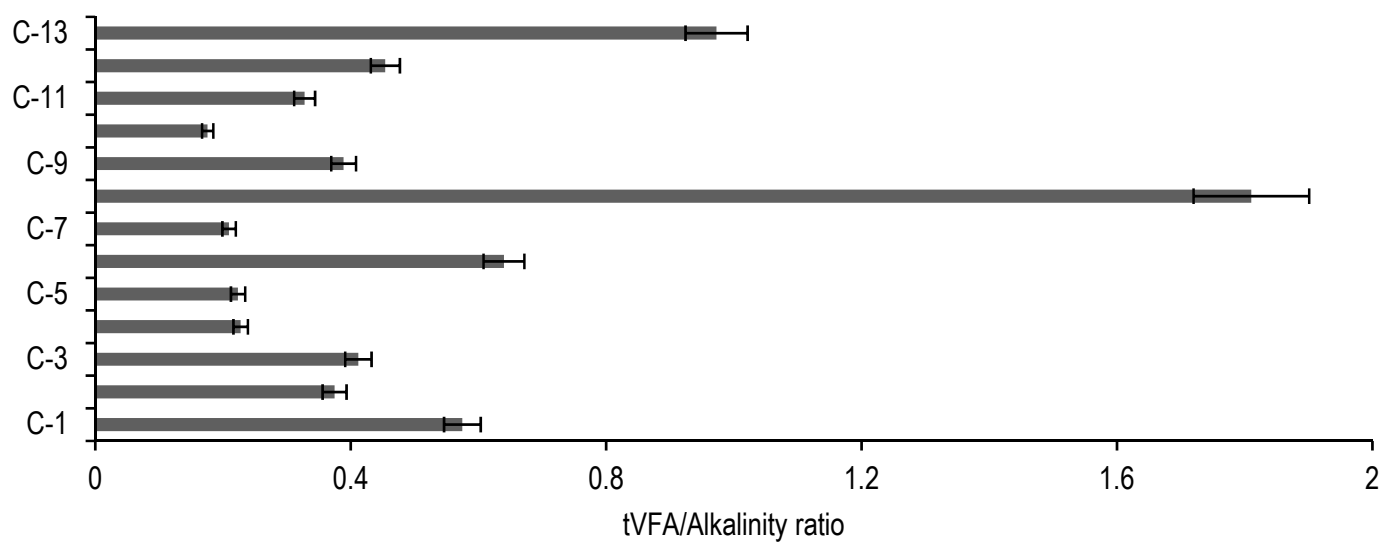

Figure 3. The tVFA/Alkalinity ratio for each combination at the end of the experimentation.

The results were similar for the combinations whose presented inhibitions have sewage sludge as the only nitrogen provider or in a 1:1 relation with pig manure. Sewage sludge has an initial concentration of VFA $\left(792 \mathrm{mg} \mathrm{L}^{-1}\right)$, which might not be consumed then, along with other conditions, reduces the buffer capacity of the system, and leads to the acidification by the accumulation of VFA.

Otherwise, intermediate and high loading rates are suitable in low $\mathrm{C} / \mathrm{N}$ ratios, achieving stable biogas yields, given the semi-continuous regime and the hydrodynamics that contributes to the evolution, mass transfer, structure and metabolism of the microbial community [45].

Along with the monitoring results, combinations 6, 8, 9 and 11 presented high productions of VFAs (1526.4-2064 $\mathrm{mg} \mathrm{L}^{-1}$ ) during the first day of the process, resulting in recurrent $\mathrm{pH}$ variations $(4.94 \pm 0.13)$, generating partial inhibition of methanogenesis during the start-up period or complete failure of the anaerobic co-digestion process [10]. These combinations were submitted to the addition of chemical agents for the stabilization of the process, and the $\mathrm{pH}$ values registered were 5.1 to 6.7 during the first 6 days of the process and 7 to 7.4 from day 10 to the end of the experiments. Similar behaviour was seen in combination 13, even though no inhibitions were expected since the $\mathrm{pH}$ remained between 6.22 and $6.65 \pm 0.17$, hence, a tVFA/Alkalinity ratio of 0.97 shows the process imbalance due to VFA accumulation [46]. 
As the tVFA/Alkalinity ratio (Figure 3) and pH-typical stable values for the anaerobic co-digestion process are below 0.5 and between 6.8 to 7.2 , respectively, values above 0.8 and $\mathrm{pH}$ under 6.6 demonstrate a significant inhibition of the methanogenesis [47-49]. For example, in combination 8 (C/N 45, 50\%, $4 \mathrm{~g} \mathrm{VS}$ fed day $\left.^{-1}\right)$, after the addition of sodium hydroxide to counteract the $\mathrm{pH}$ drop reached an inhibited steady-state operation at a $\mathrm{pH}$ value of 5.4, the process was interrupted at day 7 due to a total inhibition of methanogens by tVFA accumulation and the low buffer capacity of the system to counteract the $\mathrm{pH}$ drop (2064 $\mathrm{mg} \mathrm{L}^{-1}$ of tVFA). This was reflected during the monitoring, where the biogas productions were between 47.54 and $110.56 \mathrm{~mL}^{\text {day }}{ }^{-1}$ with a biogas composition of $20-26.3 \% \mathrm{CH}_{4}, 69.1 \% \mathrm{CO}_{2}$ and $1.2-0.2 \% \mathrm{O}_{2}$.

In comparison, Martínez et al., 2016 [50] reported inhibitions in the co-digestion of sludge under mesophilic conditions, finding that an initial accumulation of VFAs produced during the acid phase can inhibit the activity of acetoclastic methanogenesis. Similarly, Chen et al., 2008 [51], described that the interactions between fatty acids, volatile fatty acids and $\mathrm{pH}$ could lead to the process of developing in an inhibited stable state but with a low yield in the production of biogas.

\subsection{Statistical Analysis Results}

\subsubsection{Polynomial Model}

The daily biogas production was evaluated to generate a polynomial model from which the optimum conditions for biogas production were established (Equation (2)). The second-order polynomial takes as its variables those presented in the Box-Behnken experimental design; the interactions of the independent variables are presented as numerical values in accordance with the dependent variable. The determination coefficient of the resultant equation indicates that the model, as fitted, explains $94.5 \%$ of the variability in terms of daily biogas production as follows:

$$
\begin{gathered}
Y=1944.24+59.5969 * \alpha+4877.61 * \beta-2754.4 * \gamma+2.25795 * \alpha^{2}-78.1335 * \alpha * \beta-50.532 * \\
\alpha * \gamma-534.25 * \beta^{2}-540.727 * \beta * \gamma+826.373 * \gamma^{2}
\end{gathered}
$$

where $\alpha$ represents the $C / N$ ratio, $\beta$ denotes the percentage of the source of nitrogen and $\gamma$ indicates the organic loading rate fed daily.

The optimal condition indicated a daily biogas production of $2267.81 \mathrm{~mL} \mathrm{day}^{-1}$, with a C/N of 25 , an OLR of 4 and a proportion of $70 \%$ for the nitrogen provider percentage, which indicates pig manure as the primary source of nitrogen. These conditions are similar to those of combination 7.

On the other hand, a Pareto chart analysis determined the cumulative effect of each independent variable. As can be seen in Figure 4, the OLR has a positive effect on biogas production, followed by the $\mathrm{C} / \mathrm{N}$ ratio. These suggested the relevance of the total organic load, the mixture synergistic effect and the substrate's physicochemical characteristics.

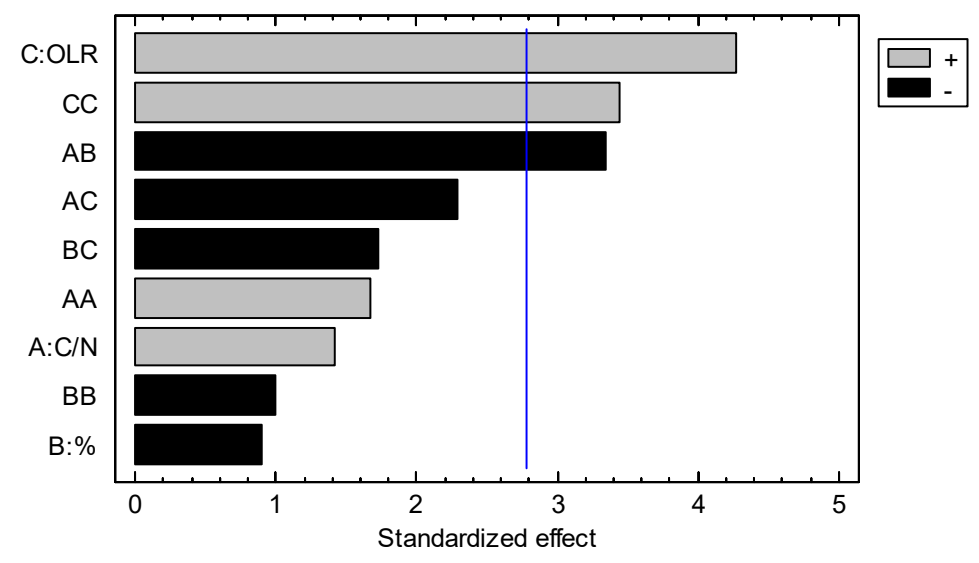

Figure 4. Pareto chart analysis for daily biogas production estimations. 
Although, the nitrogen provider and the interactions between variables presented an adverse effect indicating a possible inhibitory effect over the daily biogas production, by generating a process imbalance. Specifically, the adverse effects of the $\mathrm{C} / \mathrm{N}$ interactions can be associated to high ammonia nitrogen concentrations, which can inhibit the activity of the methanogenic stage [52]. Hence, according to the previous analysis (Section 3.1.2), the identification of the conditions that may inhibit the production of biogas is necessary for the implementation of this kind of system, in terms of the successful transfer of the technology. The operative conditions which inhibit the anaerobic digestion should be avoided, to reduce economic losses and improve the valorisation of the residual biomass in a biogas generation system.

Regarding combination 7, one of its main characteristics is the inherent buffer capacity given by the defined operational conditions, the $\mathrm{pH}$ values were increasing during the fermentation time (7.6 of $\mathrm{pH}$ as final value), which favours the process stability and the microbial development community [53], enhancing biogas yields and generating conditions during the ACoD process for biomass stabilization; with biogas yields of $617.98 \mathrm{~mL} \mathrm{~g}^{-1} \mathrm{VS}$ at day $14,78 \%$ of VS removal and $17,800 \mathrm{mg} \mathrm{L}^{-1}$ of tVFA. The comparison of this information and the model results allowed us to determine that C-7 is suitable for evaluation under real scale conditions.

\subsubsection{Combination 7 Biogas Composition}

The biogas composition was evaluated in terms of the percentage of $\mathrm{CH}_{4}, \mathrm{CO}_{2}$ and $\mathrm{O}_{2}$ produced daily. Figure 5 shows the biogas composition variation over the co-digestion time. The maximum concentration of methane $(62.5 \%)$ was reached by day 14 , as well as the stabilization in terms of biogas production for the combination selected for the reasons mentioned above (C7). In addition, biogas production started since the first day of the process, $\mathrm{CH}_{4}$ reached up to $50 \%$ on day 10 while $\mathrm{CO}_{2}$ decreased, which is related to the inoculation. The concentrations of $\mathrm{CH}_{4}$ remained stable after the production stabilization, with an average composition of $60.6 \% \mathrm{CH}_{4}, 40.1 \% \mathrm{CO}_{2}$ and $0.3 \% \mathrm{O}_{2}$. Previous studies for pilot-scale systems have similar register compositions of biogas $[41,54,55]$. This composition allows the use of the biofuel for the generation of electricity and heat.

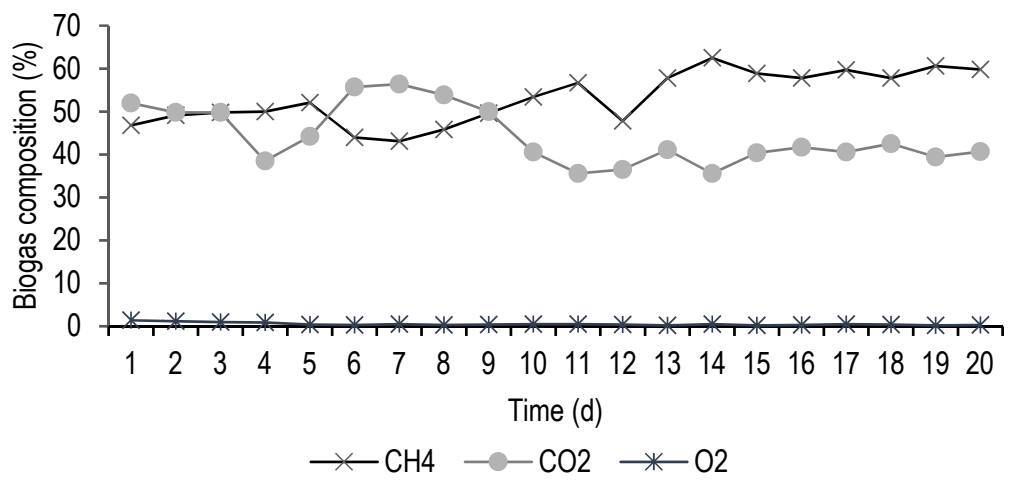

Figure 5. Biogas composition monitoring over the co-digestion process of C-7.

\subsection{Life Cycle Assessment Results}

As proposed, the LCA was based on detailed information from the availability of agro-industrial residues, the definition of process stages established according to the results obtained during the pilot-scale experiments and the corresponding assumptions.

3.3.1. Process Design and Construction of Mass and Energy Balances for the Inventory Analysis

In accordance with the residual biomass availability for the department of Cundinamarca (Colombia) and based on the data obtained from the previous pilot-scale experiments in Sections 3.2 and 3.3 of the present work, a real scale scenario was developed. The mass and 
energy flow diagram is as shown in Figure 6, the biogas production through the ACoD of the residual biomass is defined under the operative conditions evaluated in combination 7 , which for a real scale process results in $2.676 \mathrm{t}$ of residues managed daily (45.488 $\mathrm{t}$ per year). The ACoD process was followed by (a) biogas biofiltration system for hydrogen sulphide $\left(\mathrm{H}_{2} \mathrm{~S}\right)$ removal and dehydration to the combustion of the biogas in a suitable engine; (b) the separation of digestate into solid and liquid fractions for further valuation as co-products. The produced energy from the biogas transformation will be used for the internal needs of the plant, and the balance ( $369.69 \mathrm{kWh} \mathrm{day}^{-1}$ ) is integrated into the energy matrix. The emissions resulting from the combustion of the biogas are presented in Table 4.

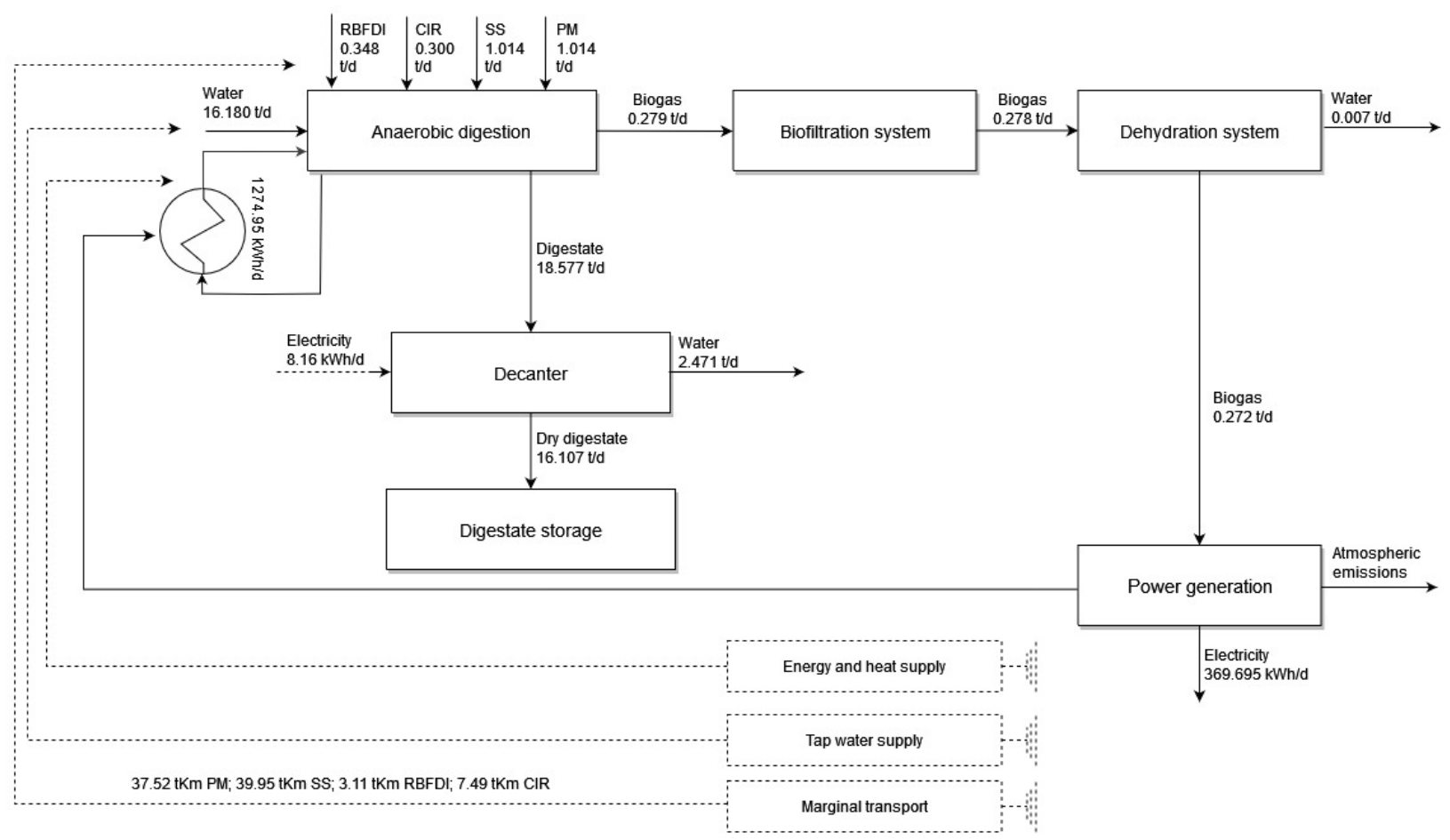

Figure 6. Mass and energy flow diagram of the tonnes of residual biomass fed per day for C-7. The grey dotted lines and boxes show the fuels, energy and resources referred from databases.

Table 4. Atmospheric emissions from the biogas combustion in the biogas engine.

\begin{tabular}{|c|c|}
\hline Emissions to Air ${ }^{\text {a }}$ & g Day $^{-1}$ \\
\hline Carbon Monoxide, Fossil & 7.62 \\
\hline Hydrogen Sulfide & $1.67 \times 10^{-01}$ \\
\hline Methane, Fossil & 7.08 \\
\hline NMVOC, Non-Methane Volatile Organic Compounds, Unspecified Origin & $7.43 \times 10^{-01}$ \\
\hline Methane, Biogenic & $4.72 \times 10^{+01}$ \\
\hline Nitrogen, Atmospheric & $5.08 \times 10^{+01}$ \\
\hline Carbon Dioxide, Biogenic & $2.53 \times 10^{+04}$ \\
\hline Carbon Disulfide & $6.27 \times 10^{-02}$ \\
\hline
\end{tabular}

a The data were taken from Ecoinvent 3 database background data.

\subsubsection{Impact Assessment Using SimaPro Software}

The SimaPro software granted inventory data modelling. The impact was assessed with the CML baseline method 2001, considering the following impact categories: the abiotic depletion of fossil fuel (ADF), global warming potential (GWP), human toxicity $(\mathrm{HT})$, terrestrial ecotoxicity (TE), acidification potential (AP), photo-oxidation formation (POF) and the eutrophication potential (EP) (see Table 5) [56,57]. For this particular system, the impact is positive for the period evaluated (daily reactor feed), even when there was no 
quantification of the avoided impacts that are key points when looking at an integrated waste management system; which determines the impact of the ACoD as a service that includes the end-use of supernatant and digestate as biofertilizer [58]. This result is consistent with previous LCA for waste to energy valorisation [59-61]. Regarding Cusenza et al. (2021) [59], it was reported that the environmental credits emerge from avoiding the production of mineral fertilizers, this would allow a reduction of the impact of more than $50 \%$. Therefore, those avoided impacts can be defined as: raw material extraction, fertilizer generation and application.

Table 5. Environmental impact categories evaluated ${ }^{a}$.

\begin{tabular}{lcc}
\hline \multicolumn{1}{c}{ Impact Category } & Unit & Total \\
\hline Abiotic Depletion of Fossil Fuels (ADF) & $\mathrm{MJ}$ & 1.05 \\
Global Warming Potential (GWP) & $\mathrm{kg} \mathrm{CO}_{2} \mathrm{eq}$ & $8.80 \times 10^{-02}$ \\
Ozone Layer Depletion (ODP) & $\mathrm{kg} \mathrm{CFC}-11 \mathrm{eq}$ & $4.58 \times 10^{-09}$ \\
Human Toxicity (HT) & $\mathrm{kg} \mathrm{1,4-DB} \mathrm{eq}$ & $3.42 \times 10^{-02}$ \\
Terrestrial Ecotoxicity (TE) & $\mathrm{kg} \mathrm{1,4-DB} \mathrm{eq}$ & $5.57 \times 10^{-02}$ \\
Photo-Oxidation Formation (POF) & $\mathrm{kg} \mathrm{C} \mathrm{H}_{4} \mathrm{eq}$ & $1.34 \times 10^{-05}$ \\
Acidification Potential (AP) & $\mathrm{kg} \mathrm{SO}_{2} \mathrm{eq}$ & $2.61 \times 10^{-04}$ \\
Eutrophication Potential (EP) & $\mathrm{kg} \mathrm{PO}_{4} \mathrm{eq}$ & $2.04 \times 10^{-04}$
\end{tabular}

a The values correspond to the management of the tonnes of residual biomass fed per day to produce $1 \mathrm{kWh}$ of energy.

In addition, the most relevant environmental aspects are related to energy consumption for the bioreactor heating and electric energy consumption. Figure 7 shows the behaviour of the impact categories. The largest contribution to global warming among the LCA is associated with the electric energy consumption, emissions from biogas combustion process contribute to $4 \%$, while contributions from the thermal energy consumption and transport represent less than 30\%. Likewise, according to the biogas generation pathway proposed, there is a high tap water consumption and derivate discharges that primary contribute to the HT and TE categories. As the residual biomass used is consider a waste stream from other industries, no impact was associated to its production [14].

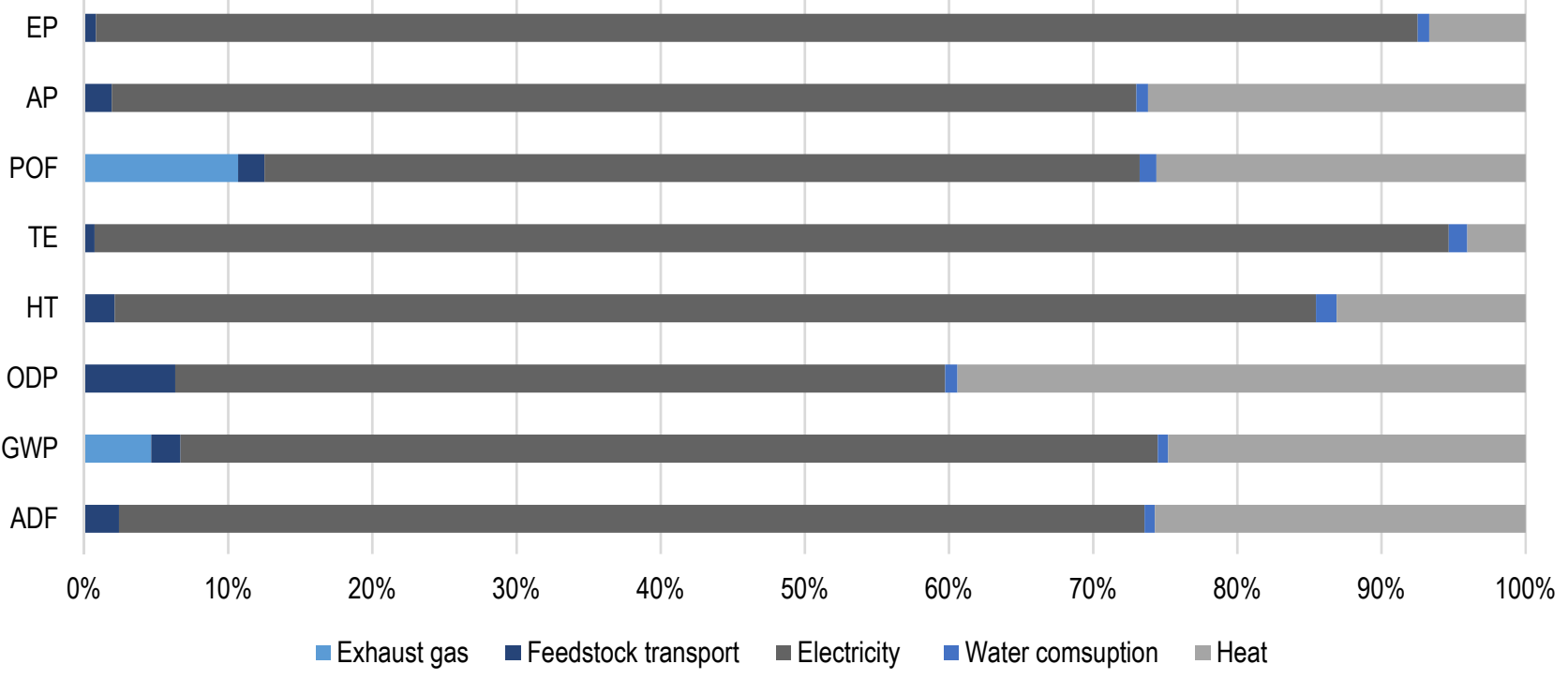

Figure 7. Contribution of the primary environmental aspects on the impact categories.

The environmental performance of the real scale plant results positive compared to the current management of the residues [13]. ACoD, as a second-generation biofuel technology, presents environmental benefits associated with the reduction of offensive odours, nutrient management, reduction of GHG emissions and waste minimization, among others [14,62]. 
The valorisation pathway proposed taking into account as its main products the biogas $(1.5 \% w / w)$ and a nutrient-rich digestate $(98.5 \% w / w)$ and clearly showed digestate as a larger and more profitable product, thus, the conversion of biogas to electric energy can be considered a secondary process [62]. Digestate as organic fertiliser contributes to the decrease in the use of synthetic fertilisers and the environmental impacts associated with its production and usage [63,64]. Hence, different researchers have developed biorefinery pathways to upcycle nutrient-rich digestate from $\mathrm{ACoD}$ processes into more profitable biobased chemicals $[13,14,41]$.

The implementation perspectives of a centralized ACoD system for the valorisation of agro-industrial residual biomass is supported in law 1715 of 2014, which aims to promote the development and use of renewable energy resources in the national energy system. Therefore, it is important to remark that these results will allow for integrating the technical, economical and environmental aspects to generate future studies and define through a decision-making tool the real implementation strategy for the process, as has been evaluated in previous research $[18,19]$.

\section{Conclusions}

The present work demonstrated that the anaerobic co-digestion of pig manure (PM), sewage sludge (SS), residues from the bottled fruit drinks industry (RBFDI) and cocoa industry residue (CIR) is favoured under low $\mathrm{C} / \mathrm{N}$ ratios (values under 35 ) and high organic loading rates (4 $\mathrm{g}$ VS); both nitrogen providers are suitable for the biogas production, although high concentrations of sewage sludge may reduce the buffer capacity of the system. As in combination 7, where the biogas yield was stable at day 14 with $617.98 \mathrm{~mL} \mathrm{~g}^{-1} \mathrm{VS}$, it is expected that this production continues in scaled processes. In general terms, $\mathrm{C} / \mathrm{N}$ ratios above 35 , together with high organic loads and only sewage sludge as a nitrogen source, affects the normal development of the process, independently of the biogas production. As shown, inhibitions can be managed through chemical agents during the initial days of the process to avoid restrictions in the AD process.

As the scale-up of the process was made by increasing the volume of the reactors, the best conditions prevail. Therefore, the assessment over the independent operational parameters and co-substrates influence allowed to propose a ACoD pathway that have significant environmental benefits. This was mainly resulting from the digestate generation, which can be upcycling for an appropriate use in agricultural activities. Focusing on GWP as the most relevant category for biogas production, the emissions calculated are $0.088 \mathrm{~kg} \mathrm{CO}_{2}$ eq/ $\mathrm{kwh}(0.024 \mathrm{~kg} \mathrm{CO} 2 \mathrm{eq} / \mathrm{MJ})$, the upcycling of the digestate will result in partial or total sequestering. For those reasons, improvements in the environmental aspects by the inclusion of this technology, along with the potential economic benefits, permits us to assure that the co-digestion process evaluated in this paper is a feasible option for the diversification of the Colombian energy matrix and the development of the agro-industrial sector.

Author Contributions: Conceptualization, J.M., P.A. and I.C.; methodology, C.R. and J.T.; software, J.M., J.T. and C.R.; validation, I.C., P.A. and A.S.; formal analysis, J.M.; investigation, all authors were involved in this aspect.; resources, I.C., P.A. and A.S.; data curation, J.M.; writing—original draft preparation, J.M.; writing—review and editing, J.M., C.R., J.T., P.A. and I.C.; supervision, I.C.; project administration, I.C. and P.A.; funding acquisition, I.C., P.A. and A.S. All authors have read and agreed to the published version of the manuscript.

Funding: This research was funded by Colciencias (Administrative Department of Science, Technology, and Innovation of Colombia), grant number FP 279-2015, and the APC was funded by Universidad Cooperativa de Colombia.

Institutional Review Board Statement: Not applicable.

Informed Consent Statement: Not applicable.

Data Availability Statement: No new data were created or analyzed in this study. Data sharing is not applicable to this article. 


\begin{abstract}
Acknowledgments: The authors acknowledge financial support from Colciencias (Administrative Department of Science, Technology, and Innovation of Colombia), project number FP 279-2015. The authors also acknowledge Walter Beltran and Dayana Alvarez from Universidad Santo Tomás and Sergio Nova from Universidad Cooperativa de Colombia the students who collaborated in the experimentation.
\end{abstract}

Conflicts of Interest: The authors declare no conflict of interest. The funders had no role in the design of the study; in the collection, analyses, or interpretation of data; in the writing of the manuscript, or in the decision to publish the results.

\title{
References
}

1. Yoo, S.-H.; Kwak, S.-Y. Electricity Consumption and Economic Growth in Seven South American Countries. Energy Policy 2010, 38, 181-188. [CrossRef]

2. Garcia, C.; Gonzalez, O.; Baez, O.; Tellez, L.; Obando, D. Plan de Acción Indicativo de Eficiencia Energética 2017-2022; Ministerio de Minas y Energía: Bogota, Colombia, 2016.

3. Unidad de Planeación Minero Energética. Available online: http://www1.upme.gov.co/InformacionCifras/Paginas/PETROLEO. aspx (accessed on 10 May 2021).

4. Rodríguez, R.; Gauthier-Maradei, P.; Escalante, H. Fuzzy spatial decision tool to rank suitable sites for allocation of bioenergy plants based on crop residue. Biomass Bioenergy 2017, 100, 17-30. [CrossRef]

5. Serna, L.V.D.; Toro, J.C.S.; Loaiza, S.S.; Perez, Y.C.; Alzate, C.A.C. Agricultural waste management through energy producing biorefineries: The Colombian case. Waste Biomass Valorization 2016, 7, 789-798. [CrossRef]

6. Yukesh Kannah, R.; Merrylin, J.; Poornima Devi, T.; Kavitha, S.; Sivashanmugam, P.; Kumar, G.; Rajesh Banu, J. Food waste valorization: Biofuels and value added product recovery. Bioresour. Technol. Rep. 2020, 11, 100524. [CrossRef]

7. Søndergaard, M.M.; Fotidis, I.A.; Kovalovszki, A.; Angelidaki, I. Anaerobic co-digestion of agricultural byproducts with manure for enhanced biogas production. Energy Fuels 2015, 29, 8088-8094. [CrossRef]

8. Pastor-Poquet, V.; Papirio, S.; Trably, E.; Rintala, J.; Escudié, R.; Esposito, G. Semi-continuous mono-digestion of OFMSW and co-digestion of OFMSW with beech sawdust: Assessment of the maximum operational total solid content. J. Environ. Manag. 2019, 231, 1293-1302. [CrossRef] [PubMed]

9. Hagos, K.; Zong, J.; Li, D.; Liu, C.; Lu, X. Anaerobic co-digestion process for biogas production: Progress, challenges and perspectives. Renew. Sustain. Energy Rev. 2017, 76, 1485-1496. [CrossRef]

10. Tsapekos, P.; Kougias, P.G.; Kuthiala, S.; Angelidaki, I. Co-Digestion and model simulations of source separated municipal organic waste with cattle manure under batch and continuously stirred tank reactors. Energy Convers. Manag. 2018, 159, 1-6. [CrossRef]

11. Jingura, R.M.; Matengaifa, R. The potential for energy production from crop residues in Zimbabwe. Biomass Bioenergy 2008, 32, 1287-1292. [CrossRef]

12. Katuwal, H.; Bohara, A.K. Biogas: A Promising Renewable Technology and Its Impact on Rural Households in Nepal. Renew. Sustain. Energy Rev. 2009, 13, 2668-2674. [CrossRef]

13. Duan, N.; Khoshnevisan, B.; Lin, C.; Liu, Z.; Liu, H. Life cycle assessment of anaerobic digestion of pig manure coupled with different digestate treatment technologies. Environ. Int. 2020, 137, 105522. [CrossRef]

14. Ingrao, C.; Bacenetti, J.; Adamczyk, J.; Ferrante, V.; Messineo, A.; Huisingh, D. Investigating energy and environmental issues of agro-biogas derived energy systems: A comprehensive review of life cycle assessments. Renew. Energy 2019, 136, $296-307$. [CrossRef]

15. Ruiz, D.; Miguel, G.S.; Corona, B.; Gaitero, A.; Domínguez, A. Environmental and economic analysis of power generation in a thermophilic biogas plant. Sci. Total Environ. 2018, 633, 1418-1428. [CrossRef]

16. Garfí, M.; Castro, L.; Montero, N.; Escalante, H.; Ferrer, I. Evaluating environmental benefits of low-cost biogas digesters in small-scale farms in Colombia: A life cycle assessment. Bioresour. Technol. 2019, 274, 541-548. [CrossRef]

17. Mayer, F.; Bhandari, R.; Gäth, S. Critical review on life cycle assessment of conventional and innovative waste-to-energy technologies. Sci. Total Environ. 2019, 672, 708-721. [CrossRef] [PubMed]

18. Amado, M.; Carrasco, J.; Ochoa, L.D.; Rangel, C.J.; Becerra, A.P.; Cabeza, I.O.; Acevedo, P.A. Technical and environmental analysis of large-scale pig manure digestion through process simulation and life cycle assessment. Chem. Eng. Trans. 2021, 87, 439-444. [CrossRef]

19. Mendieta, O.; Castro, L.; Escalante, H.; Garfí, M. Low-cost anaerobic digester to promote the circular bioeconomy in the non-centrifugal cane sugar sector: A life cycle assessment. Bioresour. Technol. 2021, 326, 124783. [CrossRef]

20. Informe de Sostenibilidad Postobon; Postobon: Bogotá, Colombia, 2021.

21. Fondo de Estabilización de Precios del Cacao. Informe de Gestión 2019; Federación Nacional de Cacaoteros: Bogotá, Colombia, 2019.

22. Censo Pecuario Nacional Año 2021; Instituto Colombiano Agropecuario-ICA: Bogota, Colombia, 2021.

23. Vargas, A.K.N.; Calderón, J.; Velásquez, D.; Castro, M.; Núñez, D.A. Biological system analysis for domestic wastewater treatment in Colombia. Ingeniare 2020, 28, 315-322. [CrossRef]

24. Mosquera, J.; Varela, L.; Santis, A.; Villamizar, S.; Acevedo, P.; Cabeza, I. Improving anaerobic co-digestion of different residual biomass sources readily available in Colombia by process parameters optimization. Biomass Bioenergy 2020, 142, 105790. [CrossRef] 
25. Rojas, F.; Sánchez, E.J.S. Guia Ambiental Para el Cultivo Del Cacao; Ministerio de Agricultura y Desarrollo Rural: Bogota, Colombia, 2013.

26. Beniche, I.; Hungría, J.; El Bari, H.; Siles, J.A.; Chica, A.F.; Martín, M.A. Effects of C/N ratio on anaerobic co-digestion of cabbage, cauliflower, and restaurant food waste. Biomass Convers. Biorefin. 2020, 11, 2133-2145. [CrossRef]

27. Dechrugsa, S.; Kantachote, D.; Chaiprapat, S. Effects of inoculum to substrate ratio, substrate mix ratio and inoculum source on batch co-digestion of grass and pig manure. Bioresour. Technol. 2013, 146, 101-108. [CrossRef]

28. Cabeza, I.; Thomas, M.; Vásquez, A.; Acevedo, P. Anaerobic co-digestion of organic residues from different productive sectors in Colombia: Biomethanation potential assessment. Chem. Eng. Trans. 2016, 49, 385-390. [CrossRef]

29. Suarez, D.; Castellanos, J.; Acevedo, P.; Santis, A.; Rodriguez, C.; Cabeza, I.; Hernandez, M. Data processing for anaerobic digestion reactor: Instrumentation, acquisition. In Proceedings of the 15th IWA World Conference of Anaerobic Digestion, Beijing, China, 17-20 October 2017.

30. Khoshnevisan, B.; Tsapekos, P.; Alvarado-Morales, M.; Angelidaki, I. Process performance and modelling of anaerobic digestion using source-sorted organic household waste. Bioresour. Technol. 2018, 247, 486-495. [CrossRef] [PubMed]

31. Sun, H.; Wu, S.; Dong, R. Monitoring volatile fatty acids and carbonate alkalinity in anaerobic digestion: Titration methodologies. Chem. Eng. Technol. 2016, 39, 599-610. [CrossRef]

32. Joyce, R.M. Experiment optimization in chemistry and chemical engineering, S. Akhnazarova and V. Kafarov, Mir Publishers, Moscow and Chicago, 1982, 312 pp. Price: \$9.95. J. Polym. Sci. Polym. Lett. Ed. 1984, 22, 372. [CrossRef]

33. Mäkelä, M. Experimental design and response surface methodology in energy applications: A tutorial review. Energy Convers. Manag. 2017, 151, 630-640. [CrossRef]

34. Ferreira, S.L.C.; Lemos, V.A.; de Carvalho, V.S.; da Silva, E.G.P.; Queiroz, A.F.S.; Felix, C.S.A.; da Silva, D.L.F.; Dourado, G.B.; Oliveira, R.V. Multivariate optimization techniques in analytical chemistry-An overview. Microchem. J. 2018, 140, 176-182. [CrossRef]

35. ISO 14040. Environmental Management_Life Cycle Assessment_Principles and Framework; International International Standard for Organization: Geneva, Switzerland, 2006.

36. Pöschl, M.; Ward, S.; Owende, P. Evaluation of energy efficiency of various biogas production and utilization pathways. Appl. Energy 2010, 87, 3305-3321. [CrossRef]

37. Li, L.; Peng, X.; Wang, X.; Wu, D. Anaerobic digestion of food waste: A review focusing on process stability. Bioresour. Technol. 2018, 248, 20-28. [CrossRef]

38. Shahbaz, M.; Ammar, M.; Korai, R.M.; Ahmad, N.; Ali, A.; Khalid, M.S.; Zou, D.; Li, X.J. Impact of C/N ratios and organic loading rates of paper, cardboard and tissue wastes in batch and CSTR anaerobic digestion with food waste on their biogas production and digester stability. SN Appl. Sci. 2020, 2,1-13. [CrossRef]

39. Alvarez, R.; Lidén, G. Semi-continuous co-digestion of solid slaughterhouse waste, manure, and fruit and vegetable waste. Renew. Energy 2008, 33, 726-734. [CrossRef]

40. Gou, C.; Yang, Z.; Huang, J.; Wang, H.; Xu, H.; Wang, L. Effects of temperature and organic loading rate on the performance and microbial community of anaerobic co-digestion of waste activated sludge and food waste. Chemosphere 2014, 105, 146-151. [CrossRef] [PubMed]

41. Khoshnevisan, B.; Tabatabaei, M.; Tsapekos, P.; Rafiee, S.; Aghbashlo, M.; Lindeneg, S.; Angelidaki, I. Environmental life cycle assessment of different biorefinery platforms valorizing municipal solid waste to bioenergy, microbial protein, lactic and succinic acid. Renew. Sustain. Energy Rev. 2020, 117, 109493. [CrossRef]

42. Bajpai, P. Process parameters affecting anaerobic digestion. In Anaerobic Technology in Pulp and Paper Industry; Springer: Berlin/Heidelberg, Germany, 2017.

43. Kougias, P.G.; Angelidaki, I. Biogas and its opportunities-A review. Front. Environ. Sci. Eng. 2018, 12, 14. [CrossRef]

44. Fan, Y.; Yang, X.; Lei, Z.; Adachi, Y.; Kobayashi, M.; Zhang, Z.; Shimizu, K. Novel insight into enhanced recoverability of acidic inhibition to anaerobic digestion with nano-bubble water supplementation. Bioresour. Technol. 2021, 326, 124782. [CrossRef]

45. Singh, B.; Szamosi, Z.; Siménfalvi, Z. State of the art on mixing in an anaerobic digester: A review. Renew. Energy 2019, 141, 922-936. [CrossRef]

46. Li, L.; He, Q.; Zhao, X.; Wu, D.; Wang, X.; Peng, X. Anaerobic digestion of food waste: Correlation of kinetic parameters with operational conditions and process performance. Biochem. Eng. J. 2018, 130, 1-9. [CrossRef]

47. Ward, A.J.; Hobbs, P.J.; Holliman, P.J.; Jones, D.L. Optimisation of the anaerobic digestion of agricultural resources. Bioresour. Technol. 2008, 99, 7928-7940. [CrossRef]

48. Nges, I.A.; Björnsson, L. High methane yields and stable operation during anaerobic digestion of nutrient-supplemented energy crop mixtures. Biomass Bioenergy 2012, 47, 62-70. [CrossRef]

49. Bouallagui, H.; Lahdheb, H.; Romdan, E.B.; Rachdi, B.; Hamdi, M. Improvement of fruit and vegetable waste anaerobic digestion performance and stability with co-substrates addition. J. Environ. Manag. 2009, 90, 1844-1849. [CrossRef]

50. Martínez, E.J.; Gil, M.V.; Fernandez, C.; Rosas, J.G.; Gómez, X. Anaerobic codigestion of sludge: Addition of butcher's fat waste as a cosubstrate for increasing biogas production. PLoS ONE 2016, 11, e0153139. [CrossRef] [PubMed]

51. Chen, Y.; Cheng, J.J.; Creamer, K.S. Inhibition of anaerobic digestion process: A review. Bioresour. Technol. 2008, 99, 4044-4064. [CrossRef] [PubMed] 
52. Pan, Y.; Zhi, Z.; Zhen, G.; Lu, X.; Bakonyi, P.; Li, Y.-Y.; Zhao, Y.; Rajesh Banu, J. Synergistic effect and biodegradation kinetics of sewage sludge and food waste mesophilic anaerobic co-digestion and the underlying stimulation mechanisms. Fuel 2019, 253, 40-49. [CrossRef]

53. Khan, M.A.; Ngo, H.H.; Guo, W.S.; Liu, Y.; Nghiem, L.D.; Hai, F.I.; Deng, L.J.; Wang, J.; Wu, Y. Optimization of process parameters for production of volatile fatty acid, biohydrogen and methane from anaerobic digestion. Bioresour. Technol. 2016, 219, 738-748. [CrossRef]

54. Liu, X.; Gao, X.; Wang, W.; Zheng, L.; Zhou, Y.; Sun, Y. Pilot-scale anaerobic co-digestion of municipal biomass waste: Focusing on biogas production and GHG reduction. Renew. Energy 2012, 44, 463-468. [CrossRef]

55. Stan, C.; Collaguazo, G.; Streche, C.; Apostol, T.; Cocarta, D.M. Pilot-Scale anaerobic co-digestion of the OFMSW: Improving biogas production and startup. Sustainability 2018, 10, 1939. [CrossRef]

56. Bacenetti, J.; Sala, C.; Fusi, A.; Fiala, M. Agricultural anaerobic digestion plants: What LCA studies pointed out and what can be done to make them more environmentally sustainable. Appl. Energy 2016, 179, 669-686. [CrossRef]

57. Rigon, M.R.; Zortea, R.; Moraes, C.A.M.; Modolo, R.C.E. Suggestion of life cycle impact assessment methodology: Selection criteria for environmental impact categories. In New Frontiers on Life Cycle Assessment-Theory and Application; IntechOpen: London, UK, 2019.

58. Edwards, J.; Othman, M.; Crossin, E.; Burn, S. Anaerobic co-digestion of municipal food waste and sewage sludge: A comparative life cycle assessment in the context of a waste service provision. Bioresour. Technol. 2017, 223, 237-249. [CrossRef]

59. Cusenza, M.A.; Longo, S.; Guarino, F.; Cellura, M. Energy and environmental assessment of residual bio-wastes management strategies. J. Clean. Prod. 2021, 285, 124815. [CrossRef]

60. Fusi, A.; Bacenetti, J.; Fiala, M.; Azapagic, A. Life cycle environmental impacts of electricity from biogas produced by anaerobic digestion. Front. Bioeng. Biotechnol. 2016, 4, 26. [CrossRef] [PubMed]

61. Sadhukhan, J.; Sen, S.; Gadkari, S. The mathematics of life cycle sustainability assessment. J. Clean. Prod. 2021, 309, 127457. [CrossRef]

62. Vasco-Correa, J.; Khanal, S.; Manandhar, A.; Shah, A. Anaerobic digestion for bioenergy production: Global status, environmental and techno-economic implications, and government policies. Bioresour. Technol. 2018, 247, 1015-1026. [CrossRef]

63. Nkoa, R. Agricultural benefits and environmental risks of soil fertilization with anaerobic digestates: A review. Agron. Sustain. Dev. 2014, 34, 473-492. [CrossRef]

64. Ochoa, C.; Hernández, M.A.; Bayona, O.L.; Camargo, H.A.; Cabeza, I.O.; Candela, A.M. Phosphorus recovery by struvite from anaerobic co-digestion effluents during residual biomass treatment. Biomass Convers. Biorefin. 2021, 11, 261-274. [CrossRef] 